8. Hladiy, M. V., Yu. P. Polupan, D. M. Basovs'kyy, L. V. Vyshnevs'kyy, S. I. Kovtun, O. V. Sydorenko, B. Ye. Podoba, O. D. Biryukova, N. L. Rieznykova, S. L. Voytenko, P. P. Dzhus, S. V. Kuzebnyy, P. I. Sharan, O. V. Kruhlyak, A. P. Kruhlyak, Yu. V. Mil'chenko, S. V. Pryyma, Yu. M. Reznikova, I. S. Martynyuk, M. I. Bashchenko, O. M. Zhukors'kyy, O. I. Kostenko, M. M. Kvasha, O. V. Romanova, and Yu. V. Vdovychenko. 2017. Prohrama zberezhennya lokal'nykh ta znykayuchykh porid sil's'kohospodars'kykh tvaryn v Ukrayini na 2017-2025 roky (proekt) The program of maintenance of local and endangered breeds of agricultural animals is in Ukraine on 2017-2025 years (project). Chubyns'ke, 63. [Elektronnyy resurs]. - Rezhym dostupu: http://iabg.org.ua/images/stories/prog_zber.pdf (in Ukrainian).

9. Rieznykova, N. L. 2017. Navishcho nam aboryhenni porody? - Why breeds of aborigines us? Rozvedennya i henetyka tvaryn - Breeding and genetics of animals. 53:50-60 (in Ukrainian).

УДК 636.27(477).033:575.22

\title{
ОСОБЛИВОСТІ ГЕНЕТИЧНОЇ СТРУКТУРИ СІРОЇ УКРАЇНСЬКОЇ ПОРОДИ ВЕЛИКОЇ РОГАТОЇ ХУДОБИ ЗА КОМПЛЕКСНИМИ ГЕНОТИПАМИ
}

\section{Н. Б. МОХНАЧОВА}

Інститут розведення і генетики тварин імені М.В.Зубия НААН (Чубинське, Україна) nm82@i.ua

Вивчено особливості генетичної структури сірої української породи великої рогатої худоби за комплексними генотипами генів CSN3, GH, $\beta L G, T G 5$ та CAPN1530, які асоиійованіз господарсько-корисними ознаками молочної та м'ясної продуктивності.

Встановлено, щьо у сірої української породи переважають генотипи $C S N 3^{A B} / \beta L G^{B B}$ ma $\mathrm{CSN3}^{A A} / \beta L G^{B B}$, які мають у своєму складі два та три алеля $B$, які асочійовані з кращим згортанням молока при виготовленні білкововмісної продукиії. Також найбільш часто зустрічаються корови з комплексним генотипом $G H^{L L} / T G^{C T} / C A P N 1^{G G}$ ma $G H^{L L} / T G 5^{C T} / C A P N 1^{G A}$. $3 a$ геном гормону росту переважає бажаний алель $L$ та генотип $L L$, який характеризується більшою інтенсивністю росту у тварин. Відносно гену тиреоглобуліну - тут найчастіше зустрічається C алель у CC та СТ генотипах. Частота $G$ алеля виявилася найвишою за геном калпаӥну, який асоиійований із зниженням пружності м язових волоконіє бажаним для тварин м'ясного напряму продуктивності.

Ключові слова: сіра українська порода, корови, господарсько-корисні ознаки, молекулярно-генетичні маркери, алелі, QTL-маркери, ПЛР-ПДРФ

\section{PECULIARITIES OF THE GENETIC STRUCTURE OFGREY UKRAINIAN BREED CAT- TLE BY COMPLEX GENOTYPES}

\section{N. B. Mokhnachova}

Institute of Animals Breeding and Genetics nd. a. M.V.Zubets of NAAS (Chubynske, Ukraine)

The peculiarities of the genetic structure of the gray Ukrainian breed of cattle based on the complex genotypes of CSN3, GH, $\beta L G$, TG 5 and CAPN 1530 genes, which are associated with economically useful features of milk and meat productivity, were studied.

It is established that in the gray Ukrainian breed the genotypes $C S N 3^{A B} / \beta L G^{B B}$ and $C S N 3^{A A} / \beta L G^{B B}$, which have two and three alleles $B$, which are associated with the best milk coagulation in the production of protein-containing products, prevail. Also, cows with the complex genotype $G H^{L L} / T G^{C T} / C A P N 1^{G G}$ and $G H^{L L} / T G 5^{C T} / C A P N 1^{G A}$ are the most frequent. The genome of the growth hormone is dominated by the desired allele $L$ and the genotype $L L$, which is characterized by 
higher growth rates in animals. Relatively to the thyroglobulin gene, the most commonly occurring $C$ allele in the SS and CT genotypes. The frequency of the $G$ allele was the highest for the genome of cappina, it is associated with a decrease in the elasticity of muscle fibers and is a desirable for animals of the meat direction of productivity.

Keywords: grey Ukrainian breed, cows, economic-useful signs, molecular genetic markers, alleles, QTL-markers, PCR-RFLP

\section{ОСОБЕННОСТИ ГЕНЕТИЧЕСКОЙ СТРУКТУРЫ СЕРОЙ УКРАИНСКОЙ ПОРОДЫ КРУПНОГО РОГАТОГО СКОТА ПО КОМПЛЕКСНЫМ ГЕНОТИПАМ}

\section{Н. Б. МОХНАЧЕВА}

Институт разведения и генетики животных имени М.В.Зубиа НААН (Чубинское, Украина)

Изучены особенности генетической структуры серой украинской породы крупного рогатого скота по комплексным генотипам генов CSN3, GH, $\beta L G$, TG 5 и CAPN1530, ассоциированным с хозяйственно-полезными признаками молочной и мясной продуктивности.

Установлено, что в серой украинской породе преобладают генотипь $C S N 3^{A B} / \beta L G^{B B} u$ $C S N 3^{A A} / \beta L G^{B B}$, которые имеют в своем составе два и три аллеля $B$, ассоииированные с лучшей свертываемостью молока при изготовлении белковосодержащей продукции. Также наиболее часто встречаются коровы с комплексным генотипом GH $^{L L} / T^{C T} / C A P N 1^{G G} u$ $G H^{L L} / T G 5^{C T} / C A P N 1^{G A}$. По гену гормона роста преобладает желаемый аллель $L$ и генотип $L L$, которыйхарактеризуется большей интенсивностью роста у животных. Относительно гена тиреоглобулина - здесь чаще всего встречается C аллель в СC и СТ генотипах. Частота $G$ аллеля оказалась самой высокой за геном калпаина, он ассоциирован со снижением упругости мышечных волокон и является желанным для животных мясного направления продуктивности.

Ключевые слова: серая украинская порода, коровы, хозяйственно-полезные признаки, молекулярно-генетические маркеры, аллели, QTL-маркеры, ПЦР-ПДРФ

Вступ. Зменшення національних генетичних ресурсів або генофондів тварин і рослин це один із ризиків індустріалізації сільського господарства. Втрата породної різноманітності разом із зникненням унікальних генетичних комбінацій веде до обмеження можливості селекційної роботи.

Зрозуміло, що основною умовою збереження локальних порід тварин є виявлення їх генетичного різноманіття. Тварини аборигенних порід володіють чудовою резистентністю по відношенню до багатьох захворювань, міцною конституцією, вони адаптовані конкретних умов середовища, що дозволяє використовувати їх при удосконаленні існуючих і створюваних порід. При збереженні аборигенних порід важливо зберегти не тільки зовнішній вигляд і біологічні властивості тварин, а саме унікальні гени і їх комбінації [1].

У більшості країн світу є свої місцеві (аборигенні) породи тварин, вклад яких у виробництво продовольства і сільськогосподарської продукції потенційно міг би бути значно більшим та вагомішим. В Україні до таких аборигенних порід належить українська сіра порода великої рогатої худоби [2].

Сучасна молекулярна генетика дає можливість виявляти гени, асоційовані $з$ господарсько-корисними ознаками сільськогосподарських тварин. Молочна та м ясна продуктивність відносяться до складних кількісних ознак, які контролюються великою кількістю генетичних локусів. Тому підбір декількох маркерів із числа головних генів на одну ознаку дозволить більш ефективно оцінити генетичний потенціал продуктивності тварини [3].

Метою роботи було вивчення особливостей генетичної структури сірої української породи за комплексними генотипами - комбінаціями цінних генів, які впливають на молочну та м`ясну продуктивність.

Матеріали та методи досліджень. Було досліджено зразки крові $(\mathrm{n}=173)$ від корів сірої української породи з господарств ДП ДГ «Маркеєво» IТСР ім. М.Ф. Іванова НААН Ас- 
канія-Нова» - ННСГЦВ (Херсонська обл.) та ДП ««Поливанівка» ДУ ІЗК НААН (Дніпропетровська обл.). Молекулярно-генетичні дослідження проводились на базі лабораторії генетики Інституту розведення і генетики тварин імені М.В.Зубця НААН. Кров для виділення ДНК відбирали $з$ яремної вени в об'ємі 5 мл в вакуумні пробірки з сухим ЕДТА. Виділення ДНК 3 цільної крові проводили з використанням стандартного комерційного набору «ДНК-сорб-В» (виробництво АмпліСенс, ЦНІІ епідеміології МЗ РФ, Росія).

Поліморфізм генів CSN3, GH, $\beta \mathrm{LG}$, TG5 та CAPN1530 досліджували методом ПЛРПДРФ. Нуклеотидні послідовності праймерів для ампліфікації та назви рестриктаз для рестрикції продуктів ампліфікації показано в табл. 1.

1. Нуклеотидні послідовності праймерів та рестриктази

\begin{tabular}{|l|l|l|l|}
\hline \multicolumn{1}{|c|}{ Ген } & \multicolumn{1}{|c|}{ Послідовність праймера, 5'-3' } & \multicolumn{1}{c|}{ Пестриктаза } & \multicolumn{1}{c|}{ Посиланн } \\
\hline CSN3 & $\begin{array}{l}\text { GAAATCCCTACCATCAATACC } \\
\text { CCATCTACCTAGTTTAGATG }\end{array}$ & Hinf1 & Kaminski S., 1993 \\
\hline GH & $\begin{array}{l}\text { GCTGCTCCTGAGGGCCCTTC } \\
\text { GCGGCGGCACTTCATGACCC }\end{array}$ & Alu I & Lucyetal M. C., 1993 \\
\hline BLG 5 & $\begin{array}{l}\text { TGTGCTGGACACCGACTACAAAAAG } \\
\text { GCTCCCGGTATATGACCACCCTCT }\end{array}$ & Medrano J., 1990 \\
\hline TG & $\begin{array}{l}\text { GGGGATGACTACGAGTAT GACTG } \\
\text { GTGAAAATCTTGTGGAGGCTGT }\end{array}$ & PsuI & Alison V., 2007 \\
\hline CAPN1530 & $\begin{array}{l}\text { TCTTCTCAGAGAAGAGCG CAG } \\
\text { CTGCGCCATTACTATCGATC }\end{array}$ & PsyI & Page B. T. et al. 2002 \\
\hline
\end{tabular}

Суміш для проведення ПЛР у своєму складі містила: 2 мкл буфера для ДНК полімерази, 1 мкл суміші трифосфатів («Амплісенс», Росія), 0,8 мкл відповідного праймера, 0,2 мкл ДНКполімерази («Fermentas», Литва). Геномна ДНК додавалась у кількості 1,5 мкл. Загальний об’єм ДНК-суміші становив 10 мкл. Ампліфікацію сумарної ДНК з праймерами проводили на програмованому чотирьох канальному термоциклі «Терцик» («ДНК-технологія», Росія).

Продукти ПЛР були оброблені специфічними ендонуклеазами рестрикції (табл. 1) за схемою: $\mathrm{H}_{2} \mathrm{O}-3,5$ мкл, 10x буфер для ферменту - 1,0 мкл, рестриктаза - 0,5 мкл та 5,0 мкл ампліфікату на 10,0 мкл робочої суміші.

Електрофоретичне розділення фрагментів рестрикції ДНК виконували в 1,5\%, та 2\%, агарозному гелях у тріс-боратному електрофорезному буфері, згідно методичних рекомендацій [4]. Візуалізацію проводили на трансілюмінаторі в УФ світлі при довжині хвилі 380 нм після забарвлення гелю етидієм бромідом.

Розміри отриманих в ПЛР або в результаті рестрикції продуктів, виявляли за допомогою маркеру молекулярних мас, Gene Ruler TM 50 bp DNA Ladder, GeneRuler TM 100 bp DNA Ladder (“Fermentas”). Детекцію результатів проводили фотографуванням гелів цифровою камерою.

Результати, отримані в експериментальних дослідженнях, опрацьовували методом популяційно-генетичного i біометричного аналізу 3 використанням "GEN Alex 6", "Statistica" [5].

Результати досліджень. На сьогодні встановлено, що якість молока, його технологічні якості і склад сиру залежать, в першу чергу, від алелів В генів капа-казеїну і беталактоглобуліну, які діють доповнюючи один одного [6]. В результаті наших досліджень були визначені комплексні генотипи одночасно за двома генами молочних білків у сірої української породи великої рогатої худоби двох популяцій. В таблиці 2 подані дані частоти виявлених комплексних генотипів капа-казеїну та бета-лактоглобуліну.

Як видно з таблиці 2 - популяції ДП ДГ«Маркеєво» нами були виявлені тільки 7 з 9 теоретично можливих генотипів. Найбільш часто у корів сірої української породи ДП ДГ «Маркеєво» зустрічається генотип $\mathrm{CSN} 3^{\mathrm{AB}} / \beta \mathrm{LG}^{\mathrm{BB}}$ (рис. 1). Такий генотип зустрічається у третини досліджених нами корів (41 гол. або 31\%). Слід зауважити, що у кожної п'ятої корови (28 голів) виявлено генотип $\mathrm{CSN}^{\mathrm{AB}} / \beta \mathrm{LG}^{\mathrm{AB}}$. 
2. Частота комплексних генотипів CSN3/BLG

\begin{tabular}{|c|c|c|c|c|}
\hline \multirow{2}{*}{ Господарство } & \multirow{2}{*}{$\Pi / \Pi$} & \multirow{2}{*}{ Комплексні генотипи CSN3/ßLG } & \multicolumn{2}{|c|}{ Частота генотипів } \\
\hline & & & $\mathrm{n}$ & $\%$ \\
\hline \multirow{9}{*}{ ДП ДГ «Маркеєво» } & 1 & $\mathrm{AA} / \mathrm{AA}$ & 0 & 0 \\
\hline & 2 & $\mathrm{AA} / \mathrm{AB}$ & 22 & 12,1 \\
\hline & 3 & $\mathrm{AA} / \mathrm{BB}$ & 28 & 15,5 \\
\hline & 4 & $\mathrm{AB} / \mathrm{AA}$ & 0 & 0 \\
\hline & 5 & $\mathrm{AB} / \mathrm{AB}$ & 37 & 20,7 \\
\hline & 6 & $\mathrm{AB} / \mathrm{BB}$ & 55 & 31 \\
\hline & 7 & $\mathrm{BB} / \mathrm{AA}$ & 9 & 5,2 \\
\hline & 8 & $\mathrm{BB} / \mathrm{AB}$ & 18 & 10,3 \\
\hline & 9 & $\mathrm{BB} / \mathrm{BB}$ & 9 & 5,2 \\
\hline \multirow{9}{*}{ ДП «Поливанівка» } & 1 & $\mathrm{AA} / \mathrm{AA}$ & 0 & 0 \\
\hline & 2 & $\mathrm{AA} / \mathrm{AB}$ & 5 & 13,2 \\
\hline & 3 & $\mathrm{AA} / \mathrm{BB}$ & 12 & 31,5 \\
\hline & 4 & $\mathrm{AB} / \mathrm{AA}$ & 0 & 0 \\
\hline & 5 & $\mathrm{AB} / \mathrm{AB}$ & 3 & 7,9 \\
\hline & 6 & $\mathrm{AB} / \mathrm{BB}$ & 13 & 34,2 \\
\hline & 7 & $\mathrm{BB} / \mathrm{AA}$ & 0 & 0 \\
\hline & 8 & $\mathrm{BB} / \mathrm{AB}$ & 2 & 5,3 \\
\hline & 9 & $\mathrm{BB} / \mathrm{BB}$ & 3 & 7,9 \\
\hline
\end{tabular}

Генотипи CSN3 ${ }^{\mathrm{AA}} / \beta \mathrm{LG}^{\mathrm{BB}}$ (21 голів або $\left.15,5 \%\right)$ i $\mathrm{CSN}^{\mathrm{AA}} / \beta \mathrm{LG}^{\mathrm{AB}}$ (16 гол. або $12,1 \%$ ) опустились на третє і четверте місце відповідно. Частота генотипів $\mathrm{CSN}^{\mathrm{BB}} / \mathrm{BLG}^{\mathrm{AA}}, \mathrm{CSN}{ }^{\mathrm{AB}} / \beta_{\mathrm{L}} \mathrm{G}^{\mathrm{AA}}$ трохи перевищила порогове значення в $5 \%$. Два генотипи CSN3 ${ }^{\mathrm{AA}} / \beta \mathrm{LG}^{\mathrm{AA}}$ та $\mathrm{CSN}^{\mathrm{AB}} / \beta \mathrm{LG}^{\mathrm{AA}}$ у досліджених тварин сірої української породи ДП ДГ «Маркеєво» відсутні.

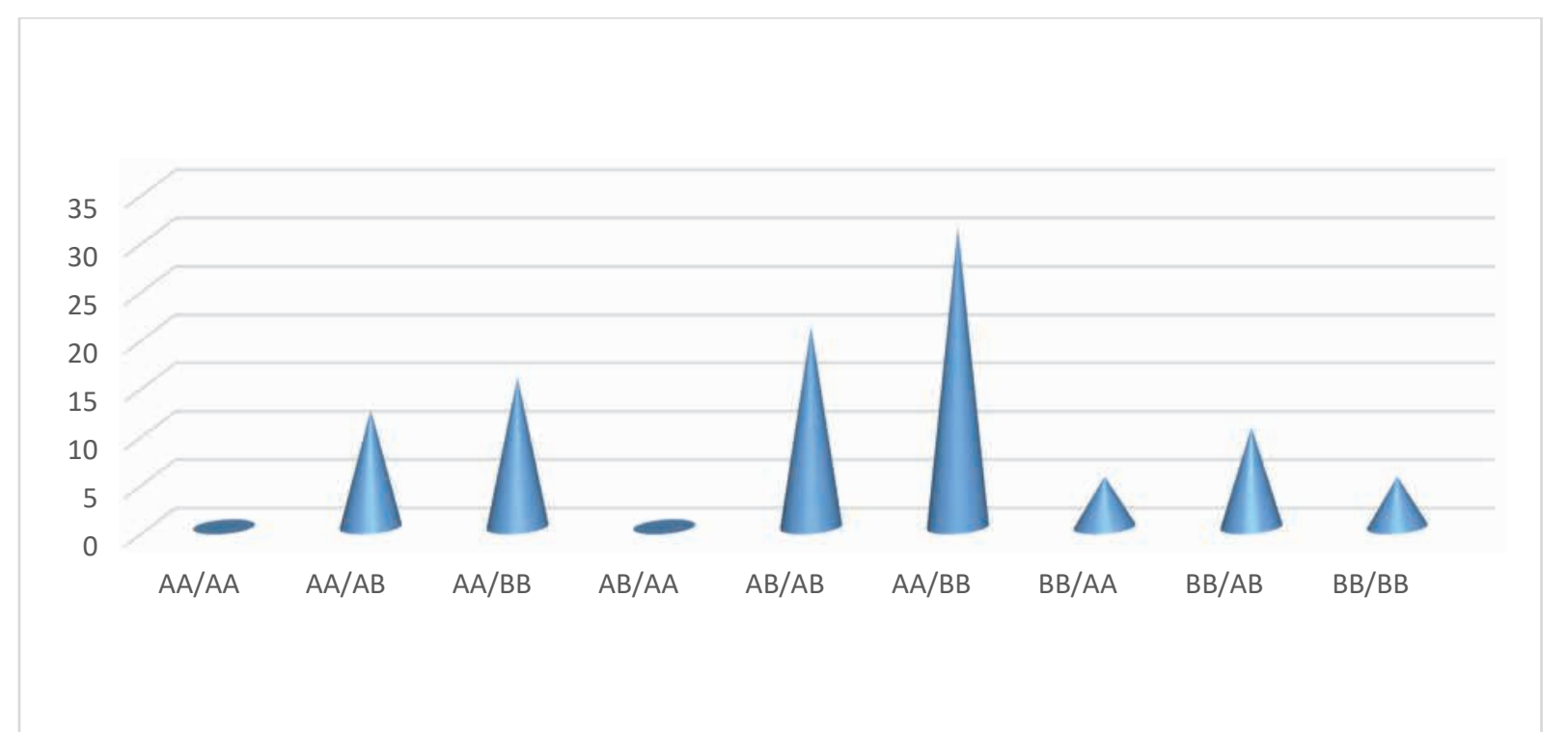

Рис. 1 Зустрічаємість комплексних генотипів CSN3/BLG у тварин сірої української породи ДП ДГ "Маркеєво"

У популяції сірої худоби з ДП «Поливанівки» ми отримали схожі результати (табл. 2). Так, у досліджених тварин із 9 теоретично очікуваних генотипів встановлено 6 комплексних генотипів за генами капа-казеїну та бета-лактоглобуліну (рис. 2). 


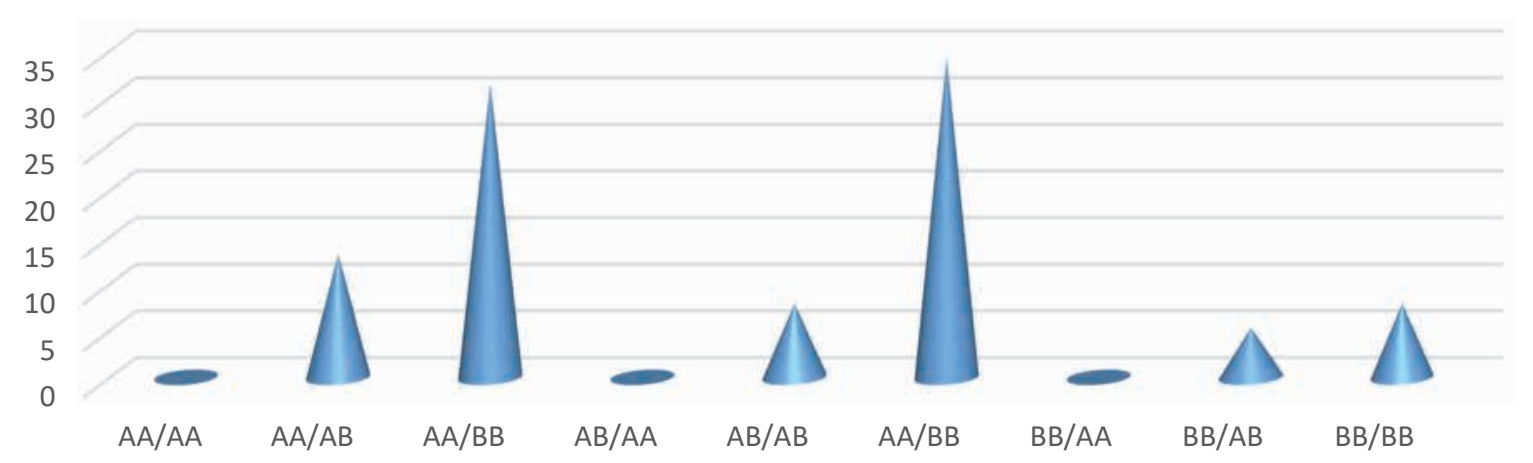

Рис. 2 Зустрічаємість комплексних генотипів CSN3/ßLG у тварин сірої української породи ДП "Поливанівка"

Лідируючі позиції серед комплексних генотипів цієї популяції займають генотипи, які містять три та два алеля В генів молочних білків відповідно: CSN3 ${ }^{\mathrm{AB}} / \beta_{\mathrm{LG}}^{\mathrm{BB}}(34,2 \%)$ та $\mathrm{CSN}^{\mathrm{AA}} / \beta \mathrm{LG}^{\mathrm{BB}}(31,5 \%)$. На третьому місці - гомозиготний за геном капа-казеїну генотип $\mathrm{CSN}^{\mathrm{AA}} / \beta \mathrm{LG}^{\mathrm{AB}}(13,2 \%)$. Цей генотип зустрічається у кожної третьої протестованої корови. Генотипи $C S N 3^{\mathrm{AB}} / \beta \mathrm{LG}^{\mathrm{AB}}$ та $\mathrm{CSN} 3^{\mathrm{BB}} / \beta \mathrm{LG}^{\mathrm{BB}}$ із однаковим значенням у $7,9 \%$ були виявлені кожної четвертої тварини. Частота генотипу $\mathrm{CSN}^{\mathrm{BB}} / \beta \mathrm{LG}^{\mathrm{AB}}$ незначно перевищила порогове значення у $5 \%$ і склала $5,3 \%$.

Відсутніми виявились 3 із 9 теоретично можливих генотипів: $\mathrm{CSN}^{\mathrm{AA}} / \mathrm{BLG}^{\mathrm{AA}}$, $\mathrm{CSN} 3^{\mathrm{AB}} / \beta \mathrm{LG}^{\mathrm{AA}}$ та $\mathrm{CSN} 3^{\mathrm{BB}} / \beta \mathrm{LG}^{\mathrm{AA}}$.

Отже, у сірої української породи переважають генотипи $\mathrm{CSN} 3^{\mathrm{AB}} / \beta \mathrm{LG}^{\mathrm{BB}}$ та $\mathrm{CSN} 3^{\mathrm{AB}} / \beta \mathrm{LG}^{\mathrm{AB}}$, які мають у своєму складі два та три алеля $\mathrm{B}$, які асоційовані з кращим згортанням молока при виготовленні білкововмісної продукції.

Нами була такожбула вивчена генетична структура поголів я сірої української породи двух популяцій одночасно за трьома генами (GH, TG5, CAPN1 530), безпосередньо пов язаних 3 м'ясною продуктивністю [8]. В таблиці 3 показана зустрічаємість комплексних генотипів GH/TG5/CAPN1 530 у корів сірої української породи.

\section{3. Частота комплексних генотипів GH/TG5/CAPN1 530}

\begin{tabular}{|c|c|c|c|c|}
\hline \multirow{2}{*}{ Господарство } & \multirow{2}{*}{$\Pi / \Pi$} & \multirow{2}{*}{ Комплексні генотипи GH/TG5/CAPN1 530} & \multicolumn{2}{|c|}{ Частота генотипів } \\
\hline & & & $\mathrm{n}$ & $\%$ \\
\hline \multirow{5}{*}{ ДП ДГ «Маркеєво» } & 1 & $\mathrm{LL} / \mathrm{CC} / \mathrm{GG}$ & 40 & 29,8 \\
\hline & 2 & $\mathrm{LL} / \mathrm{CT} / \mathrm{GG}$ & 72 & 54,8 \\
\hline & 3 & LL/TT/GG & 16 & 11,8 \\
\hline & 4 & $\mathrm{LV} / \mathrm{CC} / \mathrm{GG}$ & 2 & 1,2 \\
\hline & 5 & $\mathrm{LV} / \mathrm{CT} / \mathrm{GG}$ & 3 & 2,4 \\
\hline \multirow{11}{*}{ ДП «Поливанівка» } & 1 & $\mathrm{LL} / \mathrm{CC} / \mathrm{GG}$ & 5 & 11,8 \\
\hline & 2 & $\mathrm{LL} / \mathrm{CC} / \mathrm{GA}$ & 9 & 20,6 \\
\hline & 3 & $\mathrm{LL} / \mathrm{CT} / \mathrm{GG}$ & 2 & 5,9 \\
\hline & 4 & LL/CT/GA & 12 & 29,4 \\
\hline & 5 & LL/TT/GA & 2 & 5,9 \\
\hline & 6 & $\mathrm{LV} / \mathrm{CC} / \mathrm{GG}$ & 4 & 8,9 \\
\hline & 7 & $\mathrm{LV} / \mathrm{CC} / \mathrm{GA}$ & 1 & 2,9 \\
\hline & 8 & $\mathrm{LV} / \mathrm{CT} / \mathrm{GG}$ & 1 & 2,9 \\
\hline & 9 & LV/CT/GA & 1 & 2,9 \\
\hline & 10 & $\mathrm{LV} / \mathrm{CT} / \mathrm{AA}$ & 1 & 2,9 \\
\hline & 11 & $\mathrm{LV} / \mathrm{TT} / \mathrm{GG}$ & 2 & 5,9 \\
\hline
\end{tabular}


Iз 27 теоретично можливих комплексних генотипів у досліджених тварин ДП ДГ «Маркеєво» виявлено 5, а у популяції тварин ДП «Поливанівка» - 11.

Оцінка генетичної структури поголів`я сірої української породи показала, що серед досліджених тварин ДП ДГ «Маркеєво» найбільш часто зустрічаються корови з комплексним генотипом $\mathrm{GH}^{\mathrm{LL}} / \mathrm{TG}^{\mathrm{CT}} / \mathrm{CAPN}{ }^{\mathrm{GG}}$ (72 гол. або 54,8\%). На другому місці за частотою знаходиться генотип $\mathrm{GH}^{\mathrm{LL}} / \mathrm{TG}^{\mathrm{CC}} / \mathrm{CAPN} 1^{\mathrm{GG}} \quad(29,8 \%)$. Генотип $\mathrm{GH}^{\mathrm{LL}} / \mathrm{TG}^{\mathrm{TT}} / \mathrm{CAPN} 1^{\mathrm{GG}}$ зустрічається $з$ частотою $11,8 \%$. Перераховані «вагомі» генотипи в сумі складають $96,4 \%$ дослідженого поголів'я (рис. 3).

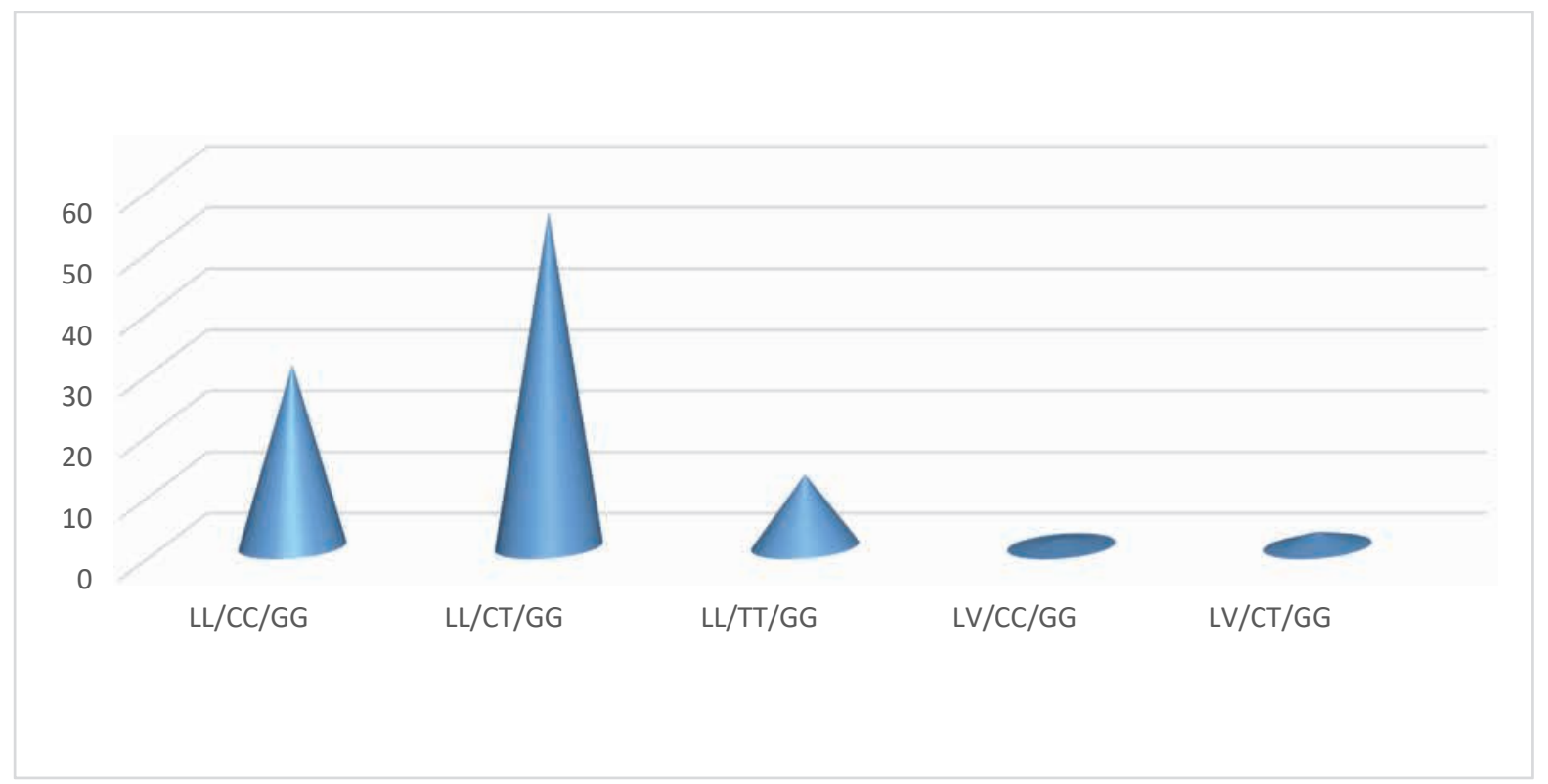

Рис. 3 Зустрічаємість комплексних генотипів GH/TG5/CAPN1 530 у тварин сірої української породи ДП ДГ "Маркеєво"

Частота решти генотипів: $\mathrm{GH}^{\mathrm{LV}} / \mathrm{TG}^{\mathrm{CC}} / \mathrm{CAPN} 1^{\mathrm{GG}} \quad(1,2 \%$ або 2 гол.) та $\mathrm{GH}^{\mathrm{LV}} / \mathrm{TG}^{\mathrm{CT}} / \mathrm{CAPN}^{\mathrm{GG}}$ (2,4\% або 3 гол.) не досягла бар`єру в $5 \%$.

Зовсім інша картина була встановлена у тварин із популяції ДП «Поливанівка». Тут із 27 теоретично можливих генотипів знайдено 11 (рис. 4). Поріг у 50\% не досяг жоден із виявлених генотипів. Позицію лідера із $29,4 \%$ тут займає генотип $\mathrm{GH}^{\mathrm{LL}} / \mathrm{TG} 5^{\mathrm{CT}} / \mathrm{CAPN} 1^{\mathrm{GA}}$. Друге та третє місце 3 частотою $20,6 \%$ та $11,8 \%$ посідають генотипи $\mathrm{GH}^{\mathrm{LL}} / \mathrm{TG} 5^{\mathrm{CC}} / \mathrm{CAPN} 1 \mathrm{GA}$ i $\mathrm{GH}^{\mathrm{LL}} / \mathrm{TG} 5^{\mathrm{CC}} / \mathrm{CAPN} 1 \mathrm{GG}$ відповідно. Також слід відмітити генотипи, які також подолали 5\% поріг $\mathrm{GH}^{\mathrm{LV}} / \mathrm{TG}^{\mathrm{CC}} / \mathrm{CAPN} 1^{\mathrm{GG}}(8,9 \%), \mathrm{GH}^{\mathrm{LL}} / \mathrm{TG} 5^{\mathrm{CT}} / \mathrm{CAPN} 1^{\mathrm{GG}}(5,9 \%) \quad \mathrm{GH}^{\mathrm{LV}} / \mathrm{TG} 5^{\mathrm{TT}} / \mathrm{CAPN} 1^{\mathrm{GG}}$ $(5,9 \%), \mathrm{GH}^{\mathrm{LL}} / \mathrm{TG}^{\mathrm{TT}} / \mathrm{CAPN} 1^{\mathrm{GA}}(5,9 \%)$.

Зазначені сім генотипів в сумі складають 88,4\% досліджуваного поголів'я (рис. 4). Генотипи $\quad \mathrm{GH}^{\mathrm{LV}} / \mathrm{TG}^{\mathrm{CC}} / \mathrm{CAPN} 1^{\mathrm{GA}}, \quad \mathrm{GH}^{\mathrm{LV}} / \mathrm{TG}^{\mathrm{CT}} / \mathrm{CAPN} 1^{\mathrm{GG}}, \quad \mathrm{GH}^{\mathrm{LV}} / \mathrm{TG}^{\mathrm{CT}} / \mathrm{CAPN} 1^{\mathrm{GA}}$, $\mathrm{GH}^{\mathrm{LV}} / \mathrm{TG}^{\mathrm{CT}} / \mathrm{CAPN} 1^{\mathrm{AA}}$ зустрічаються з рівною частотою $(2,9 \%)$.

Таким чином, в дослідженій групі тварин сірої української породи найбільш часто зустрічаються корови 3 комплексним генотипом $\mathrm{GH}^{\mathrm{LL}} / \mathrm{TG} 5^{\mathrm{CT}} / \mathrm{CAPN} 1^{\mathrm{GA}}(29,4 \%)$ та $\mathrm{GH}^{\mathrm{LL}} / \mathrm{TG} 5^{\mathrm{CC}} / \mathrm{CAPN}{ }^{\mathrm{GA}}(20,6 \%)$. За геном гормону росту переважає бажаний алель L та генотип LL, який характеризується більшою інтенсивністю росту у тварин. Відносно гену тиреоглобуліну, тут найчастіше зустрічається С алель у СС та СТ генотипах. Частота G алеля виявилася найвищою за геном калпаїну, він асоційований із зниженням пружності м язових волоконіє бажаним для тварин мясного напряму продуктивності. 


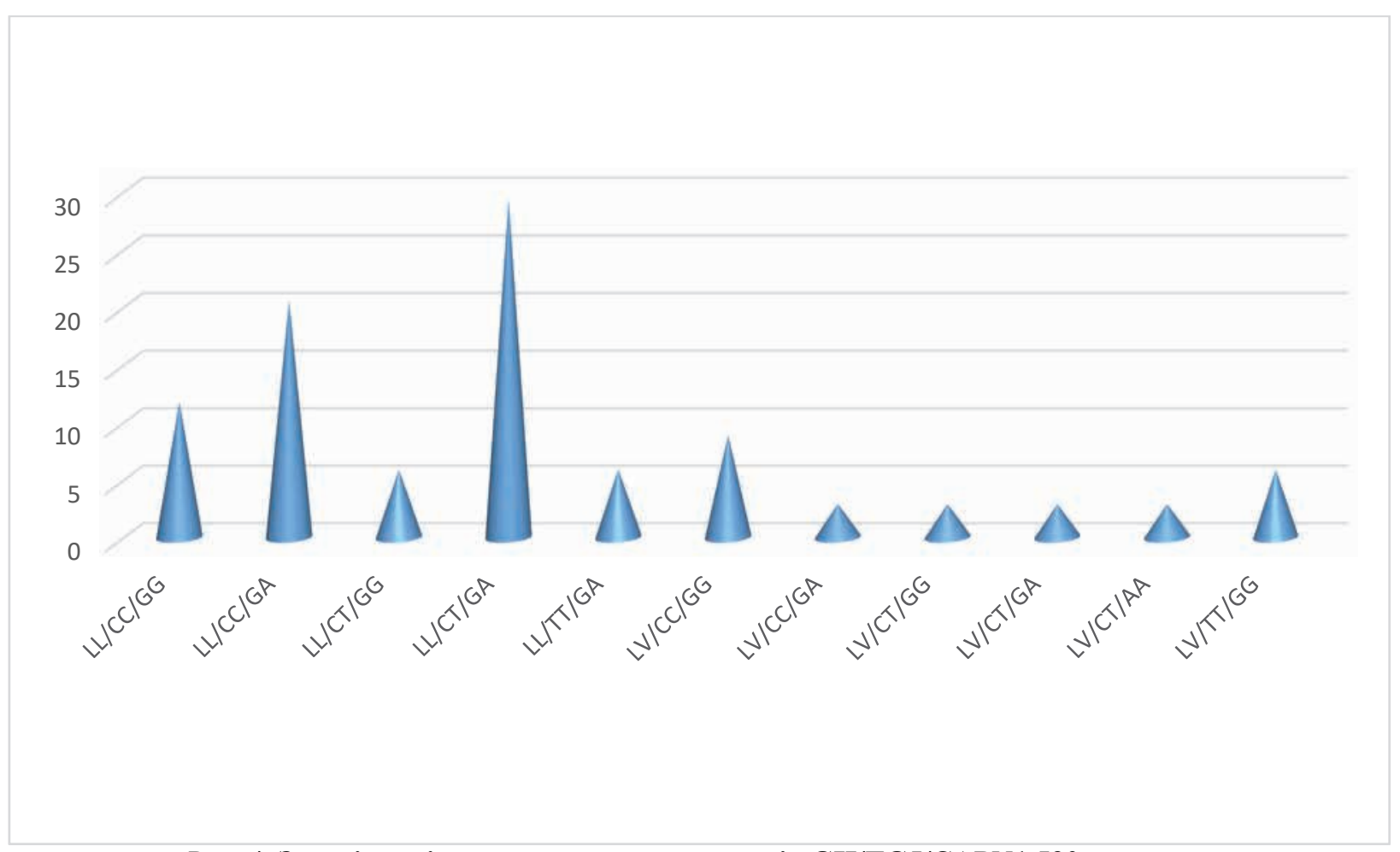

Рис. 4 Зустрічасмість комплексних генотипів GH/TG5/CAPN1 530 у тварин сірої української породи ДП "Поливанівка"

Висновки. Вивчено особливості генетичної структури сірої української породи великої рогатої худоби за комплексними генотипами генів CSN3, GH, $\beta \mathrm{LG}$, TG5 та CAPN1530, які асоційовані з господарсько-корисними ознаками молочної та м’ясної продуктивності.

Встановлено:

1. Найбільш часто у корів сірої української породи ДП ДГ «Маркеєво» зустрічається генотип $\mathrm{CSN}^{\mathrm{AB}} / \beta \mathrm{LG}^{\mathrm{BB}}$. Такий генотип зустрічається у третини досліджених нами корів (41 гол. або 31\%). Слід зауважити, що у кожної п'ятої корови (28 голів) виявлено генотип $\mathrm{CSN}^{\mathrm{AB}} / \beta \mathrm{LG}^{\mathrm{AB}}$. Два генотипи $\mathrm{CSN} 3^{\mathrm{AA}} / \beta \mathrm{LG}^{\mathrm{AA}}$ та $\mathrm{CSN}^{\mathrm{AB}} / \beta \mathrm{LG}^{\mathrm{AA}}$ у досліджених тварин сірої української породи ДП ДГ «Маркеєво» відсутні.

2. Лідируючі позиції серед комплексних генотипів ДП «Поливанівка» займають генотипи, які містять три та два алеля В генів молочних білків відповідно: $\mathrm{CSN} 3^{\mathrm{AB}} / \mathrm{\beta LG}^{\mathrm{BB}}$ $(34,2 \%)$ та $\mathrm{CSN}^{\mathrm{AA}} / \beta \mathrm{LG}^{\mathrm{BB}}(31,5 \%)$. Відсутніми виявились 3 із 9 теоретично можливих гено-

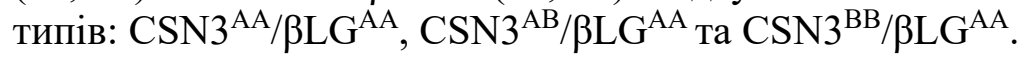

3. Серед досліджених тварин ДП ДГ «Маркеєво» найбільш часто зустрічаються корови 3 комплексним генотипом $\mathrm{GH}^{\mathrm{LL}} / \mathrm{TG}^{\mathrm{CT}} / \mathrm{CAPN} 1^{\mathrm{GG}}(72$ гол. або $54,8 \%)$.

4. В популяції ДП «Поливанівка» із 27 теоретично можливих генотипів знайдено 11. Поріг у 50\% не досяг жоден із виявлених генотипів. Позицію лідера із 29,4\% тут займає генотип $\mathrm{GH}^{\mathrm{LL}} / \mathrm{TG}^{\mathrm{CT}} / \mathrm{CAPN} 1^{\mathrm{GA}}$.

\section{БІБЛІОГРАФІЯ}

1. Генофонды сельскохозяйственных животных: генетические ресурсы животноводства / отв. ред. И. А. Захаров ; Ин-т общ. генетики им. Н.И.Вавилова РАН. - М. : Наука, 2006. - 462 с.

2. Стратегічні напрями роботи щодо збереження генофонду сільськогосподарських тварин в України / І. В. Гузєв, О. Д. Бірюкова, Л. В. Вишневський, Н. Л. Рєзнікова, О. І. Костенко // Розведення і генетика тварин. - К. : Аграрна наука, 2013. - Вип. 47. - С. 13-23.

3. Копилова, К. В. Молекулярно-генетичні маркери в системі збереження біорізноманіття сільськогосподарських тварин : автореф. дис. ... д-ра с.-г. наук : спец. 03.00.15 / К. В. Копилова; Ін-т розведення та генетики тварин, с. Чубинське Київської обл., 2012. - 36 с. 
4. Гааль, Э. Электрофорез в разделении биологических макромолекул / Э. Гааль, Г. Медьеши, Л. Верецкей. - М. : Мир, 1982. - 446 с.

5. Алтухов, Ю. П. Генетические процессы в популяциях / Ю. П. Алтухов. - М. : Наука, 1989. $-328 \mathrm{c}$.

6. Зарипов, О. Я. Генотипирование крупного рогатого скота по генам бета-лактоглобулина и каппа-казеина методами ДНК-технологии : автореф. дис. ... канд. биол. наук. : спец. 03.01.04 / О. Я. Зарипов. - Казань, 2010. - 20 с.

7. Иванченко, Е. В. Полиморфизм хозяйственно-ценных генов (бета-лактоглобулин, каппаказеин) у аутохтонных пород Украины / Е. В. Иванченко, Р. В. Облап, В. И. Глазко // Материалы науч.-ген. конф., посвящ. 100-летию со дня рожд. А. Р. Жебрака и 70-летию образования каф. генетики Московской с.-х. акад. им. К. А. Тимирязева. - М., 2002. - С. 126-128.

8. Association of thyroglobulin gene variants with carcass and meat quality traits in beef cattle / G. Y. Hou, Z. R. Yuan, H. L. Zhou, L. P. Zhang, J. Y. Li, X. Gao, D. J. Wang, H. J. Gao, S. Z. Xu // Molecular biology report. - 2011. - Vol. 38 (7). - P. 705-708.

\section{REFERENCES}

1. Zakharov, I. A. 2006. Genofondy sel'skokhozyaystvennykh zhivotnykh: geneticheskie resursy zhivotnovodstva - Gene pools farm animal: animal genetic resources.Moskva, Nauka, 462 (in Russian).

2. Huzyev, I. V., O. D. Biryukova, L. V. Vyshnevs'kyy, N. L. Ryeznikova, and O. I. Kostenko. 2013. Stratehichni napryamy roboty shchodo zberezhennya henofondu sil's'kohospodars'kykh tvaryn v Ukrayiny - Ukraine has strategic work assignments in relation to maintenance of gene pool of agricultural animals. Rozvedennya i henetyka tvaryn - Breeding and genetics of animals. 47:13-23 (in Ukrainian).

3. Kopylova, K. V. 2012. Molekuliarno-henetychni markery $v$ systemi zberezhennia bioriznomanittia silskohospodarskyk htvaryn : avtoref. dys....d-ra s.-h. nauk - Molecular genetic markers in the system of conservation of biodiversity of farm animals. Thesis doctor of agricultural sciences. 36 (in Ukrainian).

4. Gaal', E., G. Med'eshi and L. Veretskey. 1982. Elektroforez v razdelenii biologicheskikh makromolekul - Electrophoresis in the separation of biological macromolecules. Moskva, Mir, 446 (in Russian).

5. Altukhov, Yu. P. 1989. Geneticheskieprotsessy v populyatsiyakh - Genetic processes in populations. Moskva, Nauka, 328 (in Russian).

6. Zaripov, O. Ya. 2010. Gennotipirovaniye krupnogo rogatogo skota po genam betalaktoglobulina i kappa-kazeina metodami DNK-tekhnologii :avtoref. dis. ... kand. biol. nauk - Genotyping of cattle on the beta-lactoglobulin and kappa-casein genes by the methods of DNA technology : the author's abstract of the dissertation of the candidate of biological sciences. Kazan', 20 (in Russian).

7. Ivanchenko, E. V., R. V. Oblapand V. I. Glazko. 2002. Polimorfizm khozyaystvenno-tsennykh genov (beta-laktoglobulin,kappa-kazein) uautokhonnykh porod Ukrainy - Polymorphism of economically valuable genes (beta-laktoglobulin, kappa-kazein) autohonnyh rocks in Ukraine. Materialy nauch.-gen. konf.,posvyashch. 100-letiyu so dnya rozhd. A. R. Zhebrakai 70-letiyu obrazovaniya kaf. Genetiki Moskovskoys.-kh. akad. im. K. A. Timiryazeva - Materials scientific- gene. conf., is dedicated .100th anniversary of birth. A. R. Zhebrak and the 70th anniversary of the Department of Education. Moscow Agricultural Genetics Acad. them. Timiryazev. 126-128(inRussian).

8. Hou, G. Y., Z. R. Yuan, H. L. Zhou, L. P. Zhang, J. Y. Li, X. Gao, D. J. Wang, H. J. Gao, and S. Z. Xu. 2011. Association of thyroglobulin gene variants with carcass and meat quality traits in beef cattle. Molecular biology report. 38:4705-4708 (in English). 